very flame that lit up Osler's passion for medical teaching at McGill more than 120 years ago.

Eduardo L. Franco,

Professor and Director

McGill Cancer Epidemiology Unit

Departments of Oncology and of Epidemiology and Biostatistics

McGill University Faculty of Medicine

\section{WHEN POLITICS AND MEDICINE CLASH: JAMA'S EDITORIAL DECISIONS AND THE AMA}

\section{Dear MJM:}

Forget Bettie Currie and Monica Lewinsky. Add another name to the growing list of casualties resulting from the relentless saga unfolding in Washington DC: Dr. George D. Lundberg. The recent firing by the American Medical Association (AMA) of Dr. Lundberg from the position of Editor of JAMA just goes to show how politically dangerous oral sex can be, even as a topic of medical research!

The political war being waged in the Republic to the south, which ultimately revolves around sexual impropriety, has now spilled over to the world of medical scholarship. And no one is safe, not even a highly-respected medical professional and scholar such as Dr. Lundberg, a man who has been credited as having "put a small society that no one took seriously [JAMA] on the map" (1) by none other than Dr. Marcia Angell, editor of JAMA's arch-rival, the New England Journal of Medicine. So what went so drastically wrong?

According to the man responsible for the firing, AMA executive vice president, Dr. E. Ratcliffe Anderson, it wasn't so much the content of the article as the questionable timing of its publication. In fact, the main conclusions of the study, which surveyed college students on their sexual habits and beliefs in 1991, had been published previously, but the data on oral sex was somehow leftover. The fact that Dr. Lundberg decided to publish the findings on whether oral sex constituted "having sex" in the minds of these college students at the precise moment when President Clinton's impeachment trial before the Senate would be in full swing was, for Dr. Anderson, inexcusable. "I happen to believe that Dr. Lundberg was focused on sensationalism here, not science," said Dr. Andersen. "It grieves me greatly that that magnificent journal that should be about science and medicine has been used to extract political leverage"(1).
The irony here is that it is precisely Dr. Lundberg's highly controversial, and yes, sometimes questionable editorial choices at JAMA over the past seventeen years that have made it such a "magnificent journal", to use Dr. Anderson's words, and put it "on the map", as Dr. Angell so aptly put it. Recent examples include an article on the apparent benefits of alternative medicine and another on the practically untouchable issue of mercy killing.

Although a medical journal should certainly be about "science and medicine", as Dr. Andersen has argued, it should also be about raising the medically-related questions and issues that interest and perplex society, even when they happen to be distasteful, controversial, or politically-charged. In fact, it is often those precise medical issues which have the greatest need for scientific treatment and discussion so as to demystify public perceptions, or at the very least, to encourage reasoned and reasonable debate.

Furthermore, who is to say that Dr. Lundberg's decision was so obviously political and partisan? Although the inference Dr. Andersen drew from the timing of the article's publication may seem justified at first glance, on a closer look at the facts, it falls apart. Indeed it seems quite a stretch to argue that Dr. Lundberg' choice was motivated by the need to "extract political leverage" for Bill Clinton: the fact that $59 \%$ of a sample comprising a few hundred college students answered no to the question "Is oral sex 'having sex'?" is simply not going to save the President (assuming he is in any realistic danger of being removed from office, and needs saving, in the first place), because this question was never asked of Mr. Clinton in that context. As a result, the conclusions of the study are all but irrelevant to Mr. Clinton.

On the other hand, even if one concedes that this study adds little to the scientific understanding of sex strictly speaking, the fact remains that Dr. Lundberg has succeeded, once again, in stirring the pot. And isn't that also an important goal for any good medical journal? Indeed, just like all aspects of human life and activity, medicine possesses a social and political aspect, and it is the duty of any superior medical journal to acknowledge that reality and to contribute to an informed debate over the issues that have captured society's interest. That is precisely what Dr. Lundberg has tried to do with JAMA: push the envelope by mixing politics and medicine, by highlighting the sociopolitical implications of certain types of medical issues, such as, in this particular case, the way in which people conceptualize their sexuality. That is clearly a medically-relevant issue, and one worthy of scientific research and discussion, particularly at this juncture in time, precisely because of the Clinton-Lewinsky 
scandal. Yet this time, according to some, Dr. Lundberg simply went too far and, as a result, he has been made to pay a very high price: his career. Of course, it could have been worse. Thank goodness he didn't choose an article about the ill effects of cigars...

Robert H. Keller, B.A., B.C.L., LL.B'01

Student, Faculty of Law, McGill University

\section{REFERENCES}

1. Kolata G. AMA drops journal editor over sex paper. New York Times. January 16: A10; 1999.Cultural Respect

\section{CONGRATULATIONS FROM THE EDITOR OF THE MCGILL MEDICAL JOURNAL (1942)}

Dear MJM:

I learned with great pleasure of the success of the McGill Journal of Medicine. Judging by its content, I think this new journal fully deserves the praise it has received from other journals $(1,2)$.

The McGill Journal of Medicine has a predecessor called the McGill Medical Journal, which published regularly from 1931. I was Editor-in-Chief in 1942. Our principal aim was to stimulate research by students, and I think we succeeded in this. Then, as now, the Faculty of Medicine at McGill encouraged students to engage in research and publish their results.

Here at the University of Virginia, we also encourage students to engage in research. It is good to know that a journal now exists that especially welcomes papers by medical and other students. I will encourage our students to submit articles to the McGill Journal of Medicine.

With good wishes for the further success of your endeavors.

Ian Stevenson

M.D., McGill University, Class of 1943

Carlson Professor of Psychiatry

Division of Personality Studies

University of Virginia Health Sciences Center

\section{REFERENCES}

1. NEJM 336: 885; 1997

2. JAMA 278: 1461-2; 1997 